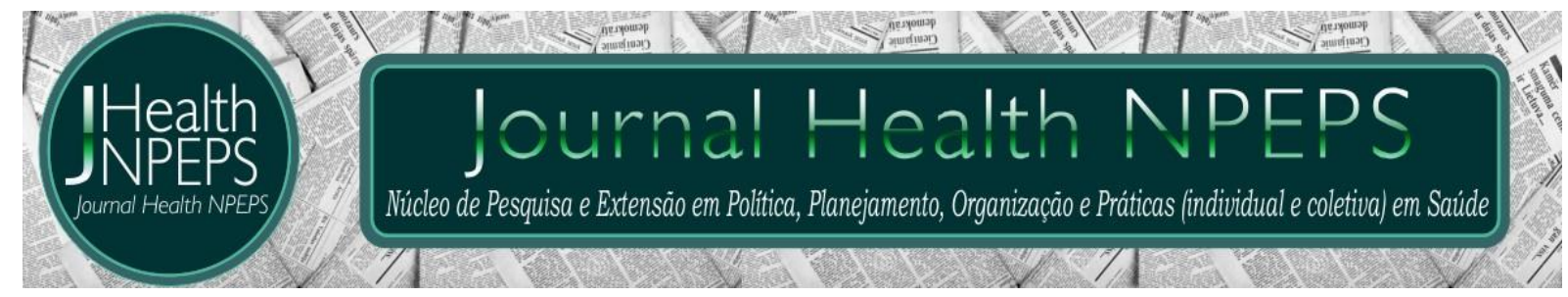

http://dx.doi.org/10.30681/252610102834

ARTIGO ORIGINAL

\title{
Microorganisms causing urinary tract infections in a teaching hospital in northeastern Brazil
}

\section{Microorganismos causantes de infecciones del tracto urinario en un hospital universitario en el noreste Brasil}

\section{Microorganismos causadores de infecções do trato urinário em um hospital universitário do nordeste do Brasil}

\begin{abstract}
Tuyanne Alves Chaves ${ }^{1}$, Cecília Brenda Rocha Carneiro ${ }^{2}$, Michael Peters ${ }^{3}$, Carlos Ney Alencar de Araújo ${ }^{4}$, Paula Karinny Mariano de Alencar ${ }^{5}$, Antonio Junior de Lima Ferreira ${ }^{6}$, Yasmine Carneiro Garcia7, Paulo Jean do Nascimento Ferreira ${ }^{8}$, Francisca Adilfa de Oliveira Garcia9
\end{abstract}

\begin{abstract}
Objective: to study the UTI-causing bacteria frequency and sensitivity profiles in a teaching hospital in northeastern Brazil. Method: A retrospective cross-sectional study was conducted based on the review of 279 patients for whom uroculture and urinary catheter cultures were routinely processed in the Microbiology Laboratory of São Vicente de Paulo Hospital. Results: For the catheter culture group, the most frequent microorganism was Staphylococcus epidermidis (47\%), while in urine culture group Escherichia coli was the microorganism most frequently isolated (52\%). E. coli showed $76.46 \%, 70 \%$, and $86.36 \%$ resistance to ampicillin, amoxicillin and Sulfamethoxazole/trimethoprim respectively. S. epidermidis showed high resistance to most drugs used, demonstrating that these drugs should not be used to treat UTIs in this institution. Conclusion: This study represents the first study evaluating bacterial resistance in this institution and since data involving epidemiological surveillance and microbiological are limited in this region and due
\end{abstract}

\footnotetext{
${ }^{1}$ Acadêmica de Medicina da Faculdade de Medicina Estácio de Juazeiro do Norte - Estácio FMJ. Juazeiro do Norte, Ceará, Brasil. E-mail: tuyanne_alves@hotmail.com ORCID ID: https://orcid.org/0000-0003-4061-1079.

${ }^{2}$ Acadêmica de Medicina da Faculdade de Medicina Estácio de Juazeiro do Norte - Estácio FMJ. Juazeiro do Norte, Ceará, Brasil. E-mail: cecilia_brenda@hotmail.com ORCID ID: https://orcid.org/0000-0002-3576-5957.

${ }^{3}$ Acadêmico de Medicina da Faculty of Sciences Health, The University of British Columbia (UBC), Vancouver, British Columbia, Canadá. E-mail: michaelpeters@gmail.com ORCID ID: https: / / orcid.org/0000-0002-3652-3220. ${ }^{4}$ Acadêmico de Medicina da Faculdade de Medicina Estácio de Juazeiro do Norte - Estácio FMJ. Juazeiro do Norte, Ceará, Brasil. E-mail: carlos_igt@yahoo.com.br ORCID ID: https://orcid.org/0000-0002-1322-7509.

${ }^{5}$ Acadêmica de Medicina da Faculdade de Medicina Estácio de Juazeiro do Norte - Estácio FMJ. Juazeiro do Norte, Ceará, Brasil. E-mail: paula_karinny@hotmail.com ORCID ID: https://orcid.org/0000-0001-7739-910X.

${ }^{6}$ Acadêmico de Medicina da Faculdade de Medicina Estácio de Juazeiro do Norte - Estácio FMJ. Juazeiro do Norte, Ceará, Brasil. E-mail: juniorjua3@hotmail.com ORCID ID: https://orcid.org/0000-0002-8439-0610.

${ }^{7}$ Acadêmica de Medicina da Universidade de Cuiabá (UNIC). Cuiabá, Mato Grosso, Brasil. E-mail: yasminecgarcia@hotmail.com ORCID ID: https://orcid.org/0000-0002-6339-5543.

${ }^{8}$ Farmacêutico. Bioquímico e Microbiologista do Hospital Maternidade São Vicente de Paulo. Barbalha, Ceará, Brasil. E-mail: paulojean@hotmail.com ORCID ID: https://orcid.org/0000-0001-8571-9484.

${ }^{9}$ Farmacêutica. Pós Doutora. Professora de microbiologia e farmacologia da Faculdade de Medicina Estácio de Juazeiro do Norte - Estácio FMJ. Juazeiro do Norte, Ceará, Brasil. E-mail: adilfabio@hotmail.com ORCID ID: https://orcid.org/0000-0001-6160-6725. Autor principal - Endereço para correspondência: Rua Maria Alves de Oliveira, 74, Bairro Alto do Jucá, Iguatu - CE, Brasil.
} 
to its importance in the national context, the results may reflect important information to the body of research/data on bacterial resistance in the world. Descriptors: Infection; Urine; Anti-Bacterial Agents.

\section{RESUMEN}

Objetivo: estudiar los perfiles de frecuencia y sensibilidad de las bacterias causantes de ITUs en un hospital universitario del nordeste brasileño. Método: Se realizó un estudio retrospectivo de corte transversal, con base en la revisión de 279 pacientes, para los cuales las culturas de urocultura y catéter urinario fueron analizadas en el Laboratorio de Microbiología del Hospital São Vicente de Paulo. Resultados: En el grupo de cultivo de catéteres, el microorganismo más frecuente fue el Staphylococcus epidermidis (47\%), mientras que en el grupo de la urocultura la Escherichia coli fue el microorganismo más aislado (52\%). La E. coli mostró $76,46 \%, 70 \%$ y $86,36 \%$ de resistencia a la ampicilina, amoxicilina y sulfametoxazol/trimetoprima, respectivamente. S. epidermidis mostró una alta resistencia a la mayoría de los fármacos utilizados indicando que los medicamentos en cuestión no deben ser usados en el tratamiento de ITUs en esa institución. Conclusión: Este estudio representa el primer estudio que evalúa la resistencia bacteriana en esa institución y una vez que los datos que involucran vigilancia epidemiológica y microbiológica son limitados en esta región y debido a su importancia en el contexto nacional, estos resultados pueden reflejar informaciones importantes para el cuerpo de búsqueda/datos sobre resistencia en el mundo.

Descriptores: Infección; Orina; Antibacterianos.

\section{RESUMO}

Objetivo: estudar os perfis de frequência e sensibilidade das bactérias causadoras de ITUs em um hospital universitário do nordeste brasileiro. Método: Foi realizado um estudo retrospectivo de corte transversal, com base na revisão de 279 pacientes, para os quais as culturas de urocultura e cateter urinário foram analisadas no Laboratório de Microbiologia do Hospital São Vicente de Paulo. Resultados: no grupo de cultura de cateteres, o microrganismo mais frequente foi o Staphylococcus epidermidis (47\%), enquanto no grupo da urocultura a Escherichia coli foi o microrganismo mais isolado (52\%). A E. coli mostrou $76,46 \%, 70 \%$ e $86,36 \%$ de resistência à ampicilina, amoxicilina e sulfametoxazol/trimetoprima, respectivamente. S. epidermidis mostrou uma alta resistência à maioria dos fármacos utilizados indicando que os medicamentos em questão não devem ser usados no tratamento de ITUs nessa instituição. Conclusão: Este estudo representa o primeiro estudo que avalia a resistência bacteriana nessa instituição e uma vez que os dados que envolvem vigilância epidemiológica e microbiológica são limitados nesta região e devido a sua importância no contexto nacional, estes resultados podem refletir informações importantes para o corpo de pesquisa/dados sobre resistência no mundo.

Descritores: Infecção; Urina; Antibacterianos.

\section{INTRODUCTION}


Exponential advances in healthcare technology has led to an increase in the sensitivity of disease detection and as a result, overtreatment, which has invariably led to increased hospitalization and complications, infections secondary to instrumentation being common ${ }^{1}$. The hospital infection rates vary from $5 \%$ to $20 \%$ and are associated with increased morbidity, mortality and hospital costs ${ }^{2}$.

A urinary tract infection (UTI) is one of the most prevalent causes of infections related to health care, and can occur in patients without typical UTI symptoms. It is also preventable as most UTIs are related to catheterization ${ }^{3}$.

Catheterization of the urinary tract is the introduction of a catheter through the urethra, allowing the flow of urine into a disposal plastic bag. This device is used in various situations, such as urinary retention, urine volume control during major surgery, or in ICU patients, particularly those with severe burns 4 .

About $80 \%$ of urinary tract infections related to health care are attributable to the use of a urinary catheter, so these patients should be the priority for epidemiological surveillance ${ }^{5}$.

The etiological agents responsible for UTIs usually belong to the natural flora of the patient, though the use of antibiotics and the lack of proper aseptic catheter care can modify the endogenous microbiota. Gram-negative bacteria such as Enterobacteriaceae are the most common, but the gram-positive bacteria also have their epidemiological relevance ${ }^{5}$.

The pathogen most commonly isolated in UTIs is Escherichia coli, though other bacteria are also often isolated including Proteus mirabilis, Klebsiella pneumoniae, Pseudomonas aeruginosa, Enterococcus spp., Enterobacter spp., Group B Streptococcus, and Staphylococcus saprophyticus. Previous use of antibiotics and variations in the local susceptibility spectrum are important predictors of resistance ${ }^{6}$.

Antibiotic treatment takes into consideration the efficacy, urinary excretion, toxicity, cost, and the dosage schedule of the drug. The delay in diagnosis of infections and the indiscriminate, empirical, or erroneous prescription of antibiotics are currently seen as responsible for the development of bacterial resistance, which is becoming a global concern ${ }^{7}$. 
Studies show that the microbial resistance level is increasing worldwide, both in hospitals and in the community. Therefore, it is extremely important to monitor the resistance of microorganisms against antibiotics in clinical practice, so that empirical treatment can still result in elimination of these pathogens ${ }^{8}$. Antibiotic resistance poses a serious threat to infection control complicating patient management and treatment strategy, contributing significantly to increase morbidity rates and mortality.

Thus, this work aims to study the UTI frequency and sensitivity profiles of the causative agents in a teaching hospital in northeastern Brazil, The hospital under study is a 270 bed Hospital, and it is part of the Unified Health System (UHS) in Brazil and is one of the major teaching hospitals of the interior of the Brazilian Northeast. HMSVP receives patients from the Cariri Metropolitan Region of Ceará and the surrounding states, serving more than 12 thousand patients monthly. Therefore, the bacterial resistance data collected at this hospital may reflect the bacterial resistance in Brazil and thus may contribute, along with other Brazilian studies, to the body of research/data on bacterial resistance in the world.

\section{METHOD}

A retrospective cross-sectional study was conducted based on the review of records of 279 patients for whom uroculture and urinary catheter cultures were processed in the Microbiology Laboratory of São Vicente de Paulo Hospital (HMSVP).

For the susceptibility test of microorganisms to antimicrobials, the samples were identified and processed following the protocols of the microbiology laboratory and the Control Center of Infections (CCIH) of the aforementioned hospital, based on the standardization proposed by the National Committee for Clinical Laboratory Standards (NCCLS) and adopted by ANVISA.

In this study, the results considered reliable were only those where antibiotics were tested in more than $50 \%$ of the bacterial strains. For resistance and susceptibility of the microorganisms was used the margin of $70 \%$ to classify the sensitive microorganisms or resistant to antibiotics. The study included all 
cultures from inpatients with a urinary tract infection, and who had their urinary cultures evaluated from January to December 2012.

The data were analyzed using SPSS version 9 and Excel. The results were summarized using tables and figures.

Ethics approval for research involving human participants was obtained according to Resolution 466/12 of the Ministry of Health and the National Health Council of Brazil ${ }^{9}$, under number 863.557 in 04/11/2014.

\section{RESULTS AND DISCUSSION}

In the period from January to December 2012, 279 samples were cultured, of which 84 were positive. Of the 55 catheter samples, 69.90\% had microbial growth. Of the 225 urine culture samples, 21\% had microbial growth (Figure 1). 41 of these patients had a community-acquired UTI, and 43 had a hospital-acquired UTI.

Most hospital-acquired urinary tract infections are closely related to catheter use, Catheter-associated (CA)-bacteriuria is the most frequent health care-associated infection worldwide, Being responsible for up to $40 \%$ of hospitalacquired infections in US hospitals each year ${ }^{10}$. A study in Brazil showed that $35 \%$ to $45 \%$ of nosocomial infections in Brazilian hospitals are UTIs ${ }^{11}$, and of these $80 \%$ are related to catheterization, which is the main risk factor and transmission vehicle.

Furthermore, it is estimated that patients catheterized for more than 30 days (long-term catheterization) nearly all of them will experience bacteriuria ${ }^{3,12}$, despite adequate aseptic technique and closed drainage systems. The risk of acquiring bacteriuria occurs between 3\% and 8\% per day of catheterization, demonstrating the cumulative risk of infection over the days of catheterization ${ }^{3}$. The high percent of positive cultures (69.90\%) in our samples support the findings of the study.

Our findings can also be compared to similar studies carried out in other Brazilian territories by authors Vieira et al. ${ }^{13}$ in the state of Pará, Kazmirczak, Giovelli and Goulart ${ }^{14}$ in the state of Rio Grande do Sul, Costa et al ${ }^{15}$ in the state of Paraiba. 
For the adequate treatment of urinary infections it is essential to identify the causative bacteria, which aids in antibiotic selection ${ }^{16}$.

Figure 2 shows that there was a different predominant etiologic agent between the investigated regions. In urinary catheter cultures the most frequent microorganism was Staphylococcus epidermidis (47\%), accompanied by Klebsiella pneumoniae (21\%). However, in non-catheterized patients Escherichia coli was the most frequent microorganism (52\%), accompanied by Pseudomonas aeruginosa (13\%), Klebisielia pneumoniae (9\%), and Staphylococcus saprofíticus (9\%).

Such findings may be justified by the fact that Staphylococcus epidermidis is a microorganism that is naturally found in the skin. However, S. epidermidis has been increasingly associated with critical infections due to the formation of bacterial biofilms in medical devices such as prostheses, valves, and catheters ${ }^{16}$. While Escherichia coli is a commensal bacterium in the intestines of humans, the anatomical proximity of the anus to the urethra, the main entry point of urinary pathogens, causes this organism to be a significant source of UTIs ${ }^{17}$. Moreover, E. coli has several attachment factors, such as several adhesins and pilis that allow it to better adhere to uroepithelium. While adherence to epithelial cells is essential for successful colonization and establishment; its virulent capacity is expressed by other encoding toxins, lipopolysaccharide (LPS), capsule, and invasins ${ }^{18}$.

With regard to the contamination of vesical catheters by Staphylococcus epidermidis, it currently ranks the first among the causative agents of biofilmrelated nosocomial infections, where the organism promotes extraluminal colonization of catheters with high antibiotic resistance. Moreover, the mechanism involved in the accumulation of staphylococcal biofilms remains not yet fully understood, it varies by strain as well as environmental conditions, which hinders the effectiveness of a specific treatment ${ }^{16,19-22}$. However, it is important to mention that Klebsiella pneumoniae, a gram-negative pathogen, was the second most frequent bacterium in patients using catheters. Furthermore, this correlates well with literature, as it the second most frequently isolated pathogen in cases of nosocomial UTIs ${ }^{23}$. 
(A) Urinary catheter

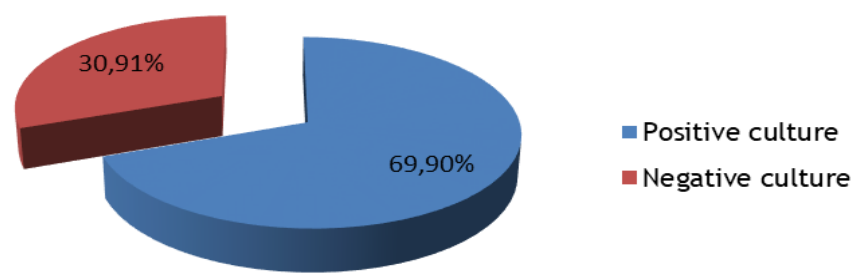

(B) Uroculture

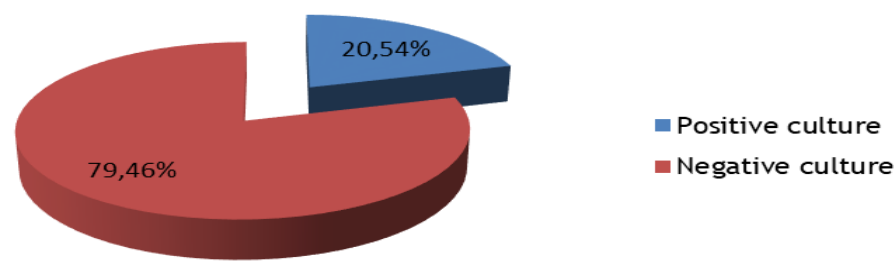

Figure 1 - Number of positive samples in urinary catheters (A) and urocultures (B).

The relationship of etiological agents isolated from urocultures presented in Figure $2 B$ showed results similar to those of the SENTRY Antimicrobial Surveillance Program by Sader et al. ${ }^{24}$, which studied the resistance of the main pathogens isolated from 12 Brazilian hospitals in four Brazilian states in a period of three years. Their results showed UTI frequency as follows: $47.6 \%$ E. coli, $12.6 \%$ P. aeruginosa, $9.8 \%$ Klebsiella pneumonia and $5.8 \%$ Enterobacter spp. It is important to mention that in our study Pseudomona aeruginosa and Klebsiella pneumonia appear colonizing both catheterized and non-catheterized patients (Figure 2), this finding may be an indicator of alertness, given the increasing mortality related to them and their high resistance rates to multiple antimicrobial drugs. Thus, only an appropriate antibiotic treatment of these infections, based on sensitivity testing and adjusting empirical antimicrobial therapy, will determine a suitable clinical evolution ${ }^{25,26}$.

It is clear that the rational use of antimicrobials should be based on the antibiogram, which allows physicians to make the correct choice of antibiotic based on its sensitivity profile. This approach reduces the rates of bacterial resistance and facilitates the correct choice of antibiotic for each patient. 
For the prudent choice of antibiotic agents, some factors must be taken into account, such as clinical efficacy against a particular group of bacteria, local resistance, and costs. Such selection has been quite effective in controlling infection, whether at the community or hospital level.

Escherichia coli was the most resistant bacterium in this study, with a resistance of $76.46 \%$ to the use of ampicillin, $70 \%$ to the use of amoxicillin, and $86.36 \%$ to the use of sulfametazol/trimetroprim (SMZ-TMP) (Table 1). It is important to say that this high resistance associated with Escherichia coli would be expected since this bacterium represented $52 \%$ of all the microorganisms isolated in the uroculture samples (Figure 2B). These results were confirmed in part by Blatt and Miranda et al. ${ }^{27}$, where Escherichia coli resistance was $60.4 \%$ for ampicillin and $54.7 \%$ for SMZ-TMP.

Regarding the highest resistance index of E. coli to SMZ-TMP in our study, a similar study carried out in northern Utah, USA, showed a resistance of $71.6 \% 28,29$, while another study carried out in the city of São Paulo, Brazil, showed that $58.3 \%$ of the strains analyzed were resistant to this medication ${ }^{28}$, demonstrating the ineffectiveness of this drug for this type of treatment.

Tavares, in 200930, reported that the indiscriminate use of SMZ-TMP in Brazil for the treatment of cystitis would become one of the main factors for the increasing resistance of UTI pathogens, due to change of the endogenous microbiota.

New resistant strains would lead to even greater therapeutic challenges. Resistance to ciprofloxacin remains low in some areas (0\% in nova scotia, Canada), but is found in $72 \%$ of isolates in Mexico and $5-10 \%$ in the USA ${ }^{31}$. Also troubling is the emergence among patients with community-acquired UTI of E. coli possessing the extended spectrum Blactamase enzymes, which confer resistance against penicillins, third generation cephalosporins, and monobactams.

In a given region, the prevalence of antibiotic resistance can not exceed $20 \%$, according to Warren et al. ${ }^{32}$ However, this study shows a resistance rate above $20 \%$ for E.coli to cephalosporins and quinolones, making its use non-viable for this population. More recent studies have shown that E. coli presents high resistance rates (>45\%) to wide-spectrum penicillins, cephalosporins, aztreonam, and ciprofloxacin ${ }^{25}$. 
However in this study, E. coli showed $100 \%$ sensitivity to aminoglycosides (amikacin and tobramycin), and carbapenems (meropenem and imipenem). Similar data were reported in the Lago, Fuentefria, and Fuentefria study ${ }^{33}$ showing $95 \%$ sensitivity, and the Miranda et al. study ${ }^{34}$ showing a sensitivity of $100 \%$ for the same drugs. These studies suggest that the use of carbapenems and aminoglycosides are well indicated in severe cases, such as chronic infections, nosocomial outbreaks, hospital-acquired infections.

\section{(A) Urinary catheter}

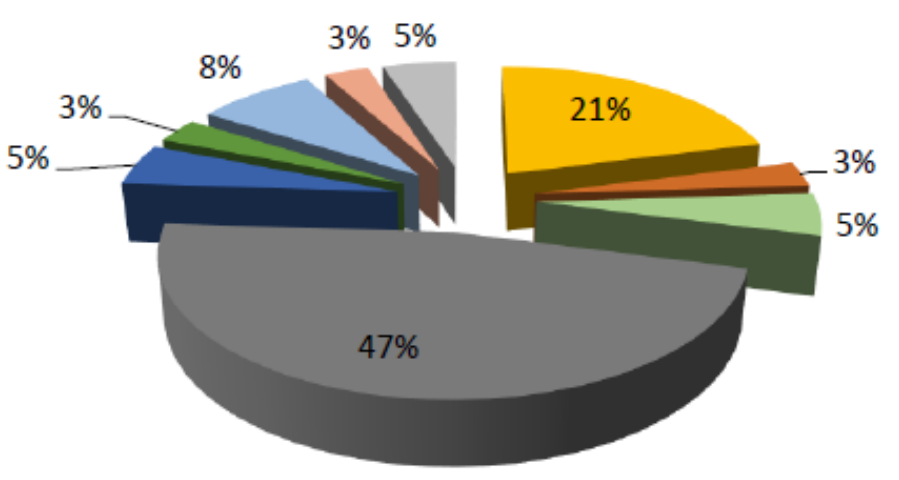

klebsiella pneumoniae

- Serratia odorífera

Serratia liquefaciens

- Staphylococcus epidermidis

Enterobacter spp

Enterobacter cloacae

- Pseudomonas aeruginosa

Staphylococcus aureus

Escherichia coli

(B) Uroculture
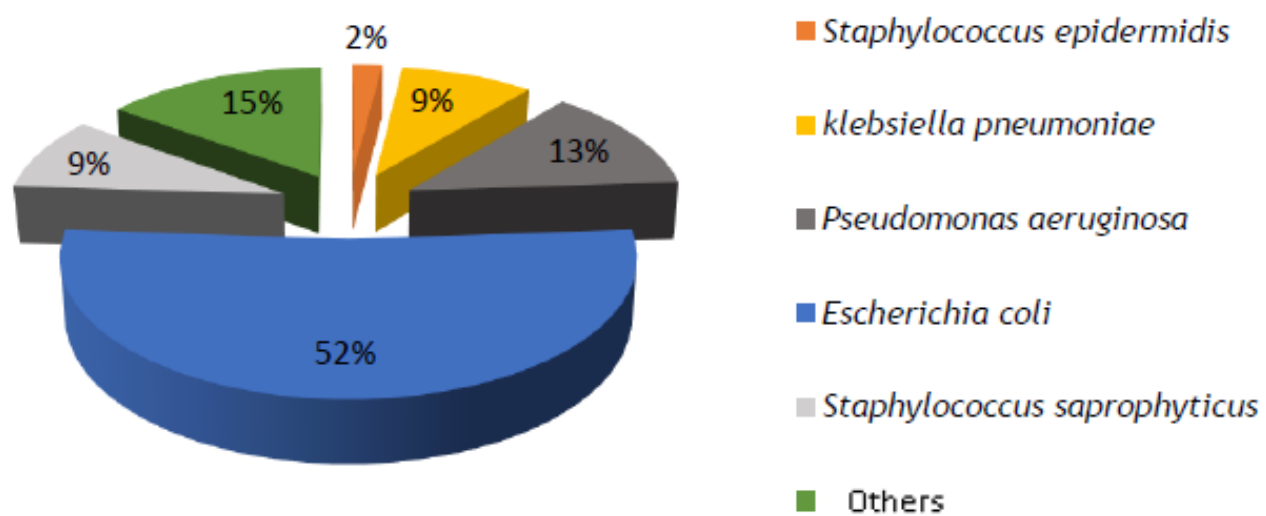

Figure 2 - Frequency of uropathogens in urinary catheter (A) and uroculture (B). 
Table 1 - Antibiogram pattern of E.coli isolated from urocultur.

\begin{tabular}{llllll}
\hline $\begin{array}{l}\text { Antimicrobial } \\
\text { agents }\end{array}$ & $\begin{array}{l}\text { Studied } \\
\text { samples }\end{array}$ & $\begin{array}{l}\text { Sensitiv } \\
(\mathrm{S})\end{array}$ & $\%(S)$ & $\begin{array}{l}\text { Resistant } \\
(\boldsymbol{R})\end{array}$ & $\%(R)$ \\
\hline imipenem & 24 & 24 & 100,0 & 0 & 0 \\
meropenem & 24 & 24 & 100,0 & 0 & 0 \\
amikacin & 24 & 24 & 100,0 & 0 & 0 \\
gentamicin & 24 & 21 & 87,50 & 3 & 12,50 \\
tobramycin & 23 & 23 & 100,0 & 0 & 0 \\
ceftazidime & 24 & 23 & 95,84 & 1 & 4,16 \\
ceftriaxone & 24 & 19 & 79,17 & 5 & 20,83 \\
cefotaxime & 24 & 19 & 73,22 & 5 & 26.78 \\
cefoxitin & 21 & 20 & 95,24 & 1 & 4,76 \\
aztreonam & 23 & 18 & 78,27 & 5 & 21,73 \\
norfloxacin & 22 & 17 & 77,28 & 5 & 22,72 \\
ciprofloxacin & 21 & 16 & 76,20 & 5 & 23,80 \\
trimethoprim- & 22 & 3 & 13,64 & 19 & 86,36 \\
sulfamethoxazole & & & & & 76,47 \\
ampicillin & 17 & 4 & 23,53 & 13 & 70,00 \\
amoxicillin & 20 & 6 & 30,00 & 14 & \\
\hline
\end{tabular}

As previously mentioned, Staphylococcus epidermidis was the most frequent bacterial agent in urinary catheter cultures, which presented high resistance to most of the drugs used, as seen in Figure $2 A$ and Table 2 . This is due to the increase in the acquisition of resistance by the genus Staphylococcus to most of currently available antimicrobial agents with anti-staphylococcal activity, such as aminoglycosides, lincosamides, macrolides, quinolones, and tetracycline. Therefore, glycopeptides, especially vancomycin, have become one of the few effective therapeutic alternatives in the treatment of infections caused by Staphylococcus, alone or in combination ${ }^{35}$.

However, some results have shown a varied efficacy of this antibiotic on the bacterial biofilm, which can be explained by its limited penetration into the biofilm matrix, which means a great challenge for clinicians making it difficult or impossible to treat and detachment from the device may result in systemic infections ${ }^{35}$.

In this study, S. epidermidis showed $100 \%$ sensitivity to vancomycin, $82.36 \%$ to amikacin, and $81.25 \%$ to chloramphenicol. Similar results were found by Michelim et al. ${ }^{36}$, where S. epidermidis was $100 \%$ sensitive to vancomycin. However, intermediate resistance to vancomycin has been described ${ }^{37}$. 
Table 2 - Antibiogram pattern of Staphylococcus epidermidis isolated from urinary catheters.

\begin{tabular}{llllll}
\hline $\begin{array}{l}\text { Antimicrobial } \\
\text { agents }\end{array}$ & $\begin{array}{l}\text { Studied } \\
\text { samples }\end{array}$ & $\begin{array}{l}\text { Sensitiv } \\
(S)\end{array}$ & $\%(S)$ & $\begin{array}{l}\text { Resistant } \\
(R)\end{array}$ & $\%(R)$ \\
\hline $\begin{array}{l}\text { vancomycin } \\
\text { amikacin }\end{array}$ & 18 & 18 & 100,00 & 0 & 0 \\
gentamicin & 17 & 14 & 82,36 & 3 & 17,64 \\
tetracycline & 19 & 9 & 47,37 & 10 & 52,63 \\
chloramphenicol & 19 & 13 & 68,43 & 6 & 31,57 \\
ciprofloxacin & 15 & 13 & 81,25 & 3 & 18,75 \\
imipenem & 19 & 11 & 73,34 & 4 & 26,66 \\
meropenem & 19 & 10 & 52,63 & 9 & 47,37 \\
cephalothin & 18 & 9 & 52,63 & 9 & 47,37 \\
cefoxitin & 18 & 9 & 50,00 & 9 & 50,00 \\
penicillin & 18 & 0 & 50,00 & 9 & 50,00 \\
erythromycin & 12 & 3 & 0 & 18 & 100,00 \\
$\begin{array}{l}\text { trimethoprim- } \\
\text { sulfamethoxazole }\end{array}$ & 18 & 7 & 25,00 & 9 & 75,00 \\
$\begin{array}{l}\text { ampicillin } \\
\text { amoxicillin }\end{array}$ & 14 & 0 & 38,89 & 11 & 61,11 \\
\hline
\end{tabular}

The increasing prevalence of highly virulent and multi-drug resistant bacterial strains constitutes a major concern in modern medicine. Biofilm formation adds an additional compounding factor, making therapy extremely difficult when there is antibiotic resistance in a subpopulation of a biofilmforming species. Pathogenic staphylococci are now regarded in the scientific community as antibiotic-resistant "superbugs," because they have the capacity to acquire resistance traits.

The difficulties of predicting a clinical infection with S. epidermidis in patients with positive blood cultures with this organism may mean management quandary for clinicians, since there are no reliable phenotypic or genotypic algorithms to predict the pathogenicity of an infection of the bloodstream by $S$ epidermidis ${ }^{38,39}$.

Possible targets for drug development include enzymes involved in the biosynthesis of cell envelope structures, such as peptidoglycan, teichoic acids, membrane lipids, or cell wall-associated adhesins ${ }^{38}$.

Epidemiological research is of fundamental importance for the proper use of antimicrobials, since the use of a particular drug in empirical therapy should not be conducted when the level of local resistance is greater than $20 \% 39$. The evolving nature of antibiograms illustrates the importance of repeating work over time, which may demonstrate possible changes either in prevalence or resistance pattern, and can provide data that can update antimicrobial therapy. 


\section{CONCLUSION}

The study identified the most frequent etiological agents and the antimicrobial susceptibility profiles of microorganisms that cause UTIs in both catheterized and non-catheterized patients while in hospital. We can conclude that $69.09 \%$ of the catheter samples had positive cultures, and that $21 \%$ of the non-catheterized samples analyzed had positive results. The majority of bacteria isolated were gram-negative enteric bacilli, with Escherichia coli having the largest portion at $52 \%$ prevalence in urocultures and with high resistance to betalactamicos and SMZ-TMP. Moreover, Staphylococcus epidermidis is the most frequent bacterial agent isolated from urinary catheters, showing high resistance to most drugs used.

This study represents the first study evaluating bacterial resistance in this Brazilian hospital and since data involving epidemiological surveillance and microbiology are limited in this region and due to its importance in the national context, the results may reflect important information to the body of research/data on bacterial resistance in the world.

\section{REFERENCES}

1. Llor C, Bjerrum L. Antimicrobial resistance: risk associated with antibiotic overuse and initiatives to reduce the problem. Ther Adv Drug Saf. 2014; $5(6): 229-41$.

2. Conterno LO, Toni D, Konkiewitz RG, Guedes ES, Barros RTD, Tiveron MG. Impact of hospital infections on patients outcomes undergoing cardiac surgery at Santa Casa de Misericórdia de Marília. Rev Bras Cir Cardiovasc. 2014; 29(2):167-76.

3. Hooton TM, Bradley SF, Cardenas DD, Colgan R, Geerlings SE, Rice JC, et al. Diagnosis, prevention, and treatment of catheter-associated urinary tract infection in adults: 2009 International Clinical Practice Guidelines from the Infectious Diseases Society of America. Clin Infect Dis. 2010; 50(5):625-63.

4. Hospital Israelita Albert Einstein. Unidade de terapia intensiva; 2014. [cited 25 mar. 2016]. Available from: http://www.einstein.br/Hospital/centro-de- 
terapia-intensiva/indicadores-de-qualidade/Paginas/infeccao-do-trato-urinarioassociada-a-sonda-vesical-na-uti-adulto.aspx.

5. Magill SS, Edwards JR, Bamberg W, Beldaus ZG, Dumyati G, Kainer MA, et al. Multistate point-prevalence survey of health care-associated infections. N Engl J Med. 2014; 370:1198-208.

6. Cunha MA, Assunção GL, Medeiros IM, Freitas MR. Antibiotic resistance pattern of urinary tract infection in a Northeastern Brazilian capital. Rev Inst Med Trop São Paulo. 2016; 58:2.

7. Lushniak BD. Antibiotic resistance: a public health crisis. Public Health Rep. 2014; 129(4):314-6.

8. Lee CR, Cho IH, Jeong BC, Lee SH. Strategies to Minimize Antibiotic Resistance. Int J Environ Res Public Health. 2013; 10(9):4274-305.

9. Brasil. Conselho Nacional de Saúde. Resolução 466/12. Trata de pesquisas em seres humanos e atualiza a resolução 196. [Internet]. Diário Oficial da União. 12 dez. 2012. Available from: http://conselho.saude.gov.br/resolucoes/2012/Reso466.pdf.

10. Centers for Disease Control and Prevention. National Nosocomial Infections Surveillance (NNIS) system report, data summary from January 1992 through June 2004, issued October 2004. Am J Infect Control. 2004; 32(8):470-85.

11. Abramczyk ML. Infecção hospitalar em unidade de terapia intensiva. In: Ministério da Saúde (BR). Agência Nacional de Vigilância Sanitária. Pediatria: prevenção e controle de infecção hospitalar. Brasília: Ministério da Saúde; 2005.

12. Smith PW, Bennett G, Bradley S, Drinka P, Lautenbach E, Marx J, et al. SHEA/APIC guideline: infection prevention and control in the long-term care facility, July 2008. Infect Control Hosp Epidemiol. 2008; 29(9):785-814.

13. Vieira JMS, Saraiva RMC, Mendonça LCV, Fernandes VO, Pinto, MRC, Vieira ABR. Susceptibilidade antimicrobiana de bactérias isoladas de infecções do trato urinário de pacientes atendidos no Hospital Universitário Bettina Ferro de Souza, Belém- PA. Rev Bras Anal Clin. 2007; 39(2):119-21.

14. Kazmirczak A, Giovelli FH, Goulart LS. Caracterização das infecções do trato urinário diagnosticadas no município de Guarani das Missões-RS. Rev Bras Anal Clin. 2005; 37(4):205-7. 
15. Costa LC. Infecções urinárias em pacientes ambulatoriais: prevalência e perfil de resistência aos antimicrobianos. Rev Bras Anal Clin. 2010; 42(3):175-80.

16. Cerca N, Gomes F, Bento JC, França A, Rolo J, Miragaia M, et al. Farnesol induces cell detachment from established S. epidermidis biofilms. J Antibiot. 2013; 66(5):255-8.

17. John AS, Mboto $\mathrm{Cl}$, Agbo $\mathrm{B}$. A review on the prevalence and predisposing factors responsible for urinary tract infection among adults. Eur $\mathrm{J}$ Experiment Biol. 2016; 6(4):7-11.

18. Lopez-Banda DA, Carrillo-Casas EM, Leyva-Leyva M, Orozco-Hoyuela G, Manjarrez-Hernandez AH, Arroyo-Escalante S, et al. Identification of virulence factors genes in Escherichia coli isolates from women with urinary tract infection in Mexico. Biomed Res Int. 2014; 2014:959206.

19. Sievert DM, Ricks P, Edwards JR, Schneider A, Patel J, Srinivasan A, et al. National Healthcare Safety Network (NHSN) Team and Participating NHSN Facilities. Antimicrobial-resistant pathogens associated with health care associated infections: summary of data reported to the National Healthcare Safety Network at the Centers for Disease Control and Prevention, 2009 -2010. Infect Control Hosp Epidemiol. 2013; 34(1):1-14.

20. Schaeffer CR, Hoang TN, Sudbeck CM, Alawi M, Tolo IE, Robinson DA, et al. Versatility of biofilm matrix molecules in Staphylococcus epidermidis clinical isolates and importance of polysaccharide intercellular adhesin expression during high shear stress. mSphere. 2016; 1(5):e00165.

21. Formosa-Dague C, Feuillie C, Beaussart A, Derclaye S, Kucharikova S, Lasa I, et al. Sticky matrix: adhesion mechanism of the Staphylococcal polysaccharide intercellular adhesin. ACS Nano. 2016; 10(3):3443-52.

22. Linnes JC, Ma H, Bryers JD. Giant extracellular matrix binding protein expression in Staphylococcus epidermidis is regulated by biofilm formation and osmotic pressure. Curr Microbiol. 2013; 66(6):627-33.

23. Foxman B. The epidemiology of urinary tract infection. Nat Rev Urol. 2010; 7(12):653-60.

24. Sader HS, Gales AC, Pfaller MA, Mendes RE, Zoccoli C, Afonso B, et al. Pathogen Frequency and Resistence Patterns in Brazilian hospitals: Sumary of results 
from three years of de SENTRY Antimicrobial Surveillence Program. Braz. J Infect Dis. 2001; 5(4):200-14.

25. Li X, Chen Y, Gao W, Ye H, Shen Z, Wen Z, et al. A 6-year study of complicated urinary tract infections in southern China: prevalence, antibiotic resistance, clinical and economic outcomes. Ther Clin Risk Manag. 2017; 13:1479-87.

26. Ferreiro JLL, Otero JÁ, González LG, Lamazares LN, Blanco AA, Sanjurjo JRB, et al. Pseudomonas aeruginosa urinary tract infections in hospitalized patients: Mortality and prognostic factors. Plos One. 2017; 12(5):e0178178.

27. Blatt JM, Miranda MC. Perfil dos microrganismos causadores de infecções do trato urinário em pacientes internados. Rev Panam Infectol. 2005; 7(4):10-4.

28. Lo DS, Shieh HH, Ragazzi SLB, Koch VHK, Martinez MB, Gilio AE. Infecção urinária comunitária: etiologia segundo idade e sexo. J Bras Nefrol. 2013; 35(2):93-8.

29. McQuilkin M, Lund A, Palmer W. Antimicrobial resistance of uncomplicated urinary tract infections in northern Utah. Clin Lab Sci. 2008; 21(2):99-101.

30. Tavares W. Antibióticos e Quimioterápicos para o Clínico. 2 ed. São Paulo: Atheneu; 2009.

31. Zhanel GG, Hisanaga TL, Laing NM, DeCorby MR, Nichol KA, Palatnik LP, et al. Antibiotic resistance in outpatient urinary isolates: final results from the North American Urinary Tract Infection Collaborative Alliance (NAUTICA). Int J Antimicrob Agents. 2005; 26(5):380-8.

32. Warren JW1, Abrutyn E, Hebel JR, Johnson JR, Schaeffer AJ, Stamm WE. Guidelines for antimicrobial treatment of uncomplicated acute bacterial cystitis and acute pyelonephritis in women. Infectious Diseases Society of America (IDSA). Clin Infect Dis. 1999; 29(4):745-58.

33. Lago A, Fuentefria SR, Fuentefria DB. Enterobactérias produtoras de ESBL em Passo Fundo, estado do Rio Grande do Sul, Brasil. Rev Soc Bras Med Trop. 2010; 43(4):430-4.

34. Miranda EJ, Oliveira GS, Roque FL, Santos SR, Olmos RD, Lotufo PA. Susceptibility to antibiotics in urinary tract infections in a secondary care setting from 2005-2006 and 2010-2011, in São Paulo, Brazil: data from 11,943 urine cultures. Rev Inst Med Trop São Paulo. 2014; 56(4):313-24. 
35. Snyder ADH, Vidaillac C, Rose W, McRoberts JP, Rybak MJ. Evaluation of highdose daptomycin versus vancomycin alone or combined with clarithromycin or rifampin against Staphylococcus aureus and $\mathrm{S}$ epidermidis in a novel in vitro PK/PD model of bacterial biofilm. Infect Dis Ther. 2015; 4(1):51-65.

36. Michelim L, Lahudel M, Araújo PR, Giovanaz DSH, Müller G, Delamare APL, et al. Pathogenic factors and antimicrobial resistance of Staphylococcus epidermidis associated with nosocomial infections occurring in intensive care units. Braz J Microbiol. 2005; 36(1):17-23.

37. Bhamare SB, Karmarkar A, lyer V, Bhardwaj R, Deshpande S, Kagal A. Study of prevalence of methicillin and vancomycin resistance in multidrug resistant coagulase negative staphylococci. Inter J Health Care Bio Med Res. 2014; 2(3):67-72.

38. Kleinschmidt S, Huygens F, Faoagali J, Rathnayake I, Hafner LM. Staphylococcus epidermidis as a cause of bacteremia. Future Microbiol. 2015; 10(11):1859-79.

39. Bail L, Ito CAS, Esmerino LA. Infecção do trato urinário: comparação entre o perfil de susceptibilidade e a terapia empírica com antimicrobianos. RBAC. 2006; 38(1):51-6.

Conflito de interesses: Os autores declaram não haver conflito de interesses.

Participação dos autores: os autores declaram que participaram de todas as etapas do estudo (concepção, desenvolvimento do estudo, redação e revisão).

Como citar este artigo: Chaves TA, Carneiro CBR, Peters $M$, Araújo CNA, Alencar PKM, Ferreira AJL, et. al. Micoorganisms causing urinary tract infections in a teaching hispital in northeastern Brazil. Journal Health NPEPS. 2018; 3(1):51-66. 